\title{
RUTGERS LIBRARIES PUBLICATIONS
}

SPRING 1981

A Guide to Manuscript Diaries and Journals in the Special Collections Department, Rutgers University. Compiled by Donald A. Sinclair.

Presented here are entertaining descriptions of 359 diaries and journals in the Rutgers collection, mostly originals, but including photocopies of a few located elsewhere. Some are short, some long (one covers seventy-three years). Some are full and informative; others spotty and thin.

Certain of the diarists were important in one way or another; the majority, however, were ordinary people-farmers, teachers, clergymen, lawyers, doctors, soldiers, students, the old and young, the rich and poor. And they lived in or visited in many places.

The arrangement of the descriptions is chronological, I743-1957, by date of initial entry. In each case there is an indication of size and scope, with sufficient analysis for potential users to judge the diary's value.

Published I980: 94 pages, soft-cover; 25-page index. Price $\$ 6.00$.

Books, Pamphlets, and Broadsides printed or published in New Jersey, i80i-i 8i 9, Not Recorded in Shaw and Shoemaker's AmeriCan Bibliography. Compiled by George C. Rockefeller, edited by Donald A. Sinclair.

George C. Rockefeller has identified and recorded 27 I titles of publications printed or published in New Jersey from I 80 I to 18 I 9 supplementing Shaw and Shoemaker's American Bibliography, $1801-1819$. In contrast to the Shaw and Shoemaker method, he prepared these descriptions from the publications themselves, except in those few cases where no location could be found.

Rockefeller's study of New Jersey imprints was virtually a lifelong project. In 1932 he began compiling a bibliography of New Jersey imprints through the year $\mathrm{I} 800$, eventually expanding greatly the pioneer work of Humphrey and Morsch. For the remaining 45 years of his life, this project, and the formation of a New Jersey imprint collection occupied him extensively.

Published I980: 38 pages, soft-cover. Price $\$ 5.00$. 
New Jersey in the American Revolution: A Bibliography of Hisrorical Fiction, from 1784. By Oral S. Coad. Second edition, slightly revised and extended to 1975, edited by Donald A. Sinclair.

New Jersey's dramatic participation in the Revolutionary War is well documented in this bibliography of historical fiction. The most famous occurrences-the Crossing of the Delaware, the Battle of Trenton, and the Battle of Monmouth - reappear again and again in this literature. Not overlooked, however, are the lesser-known episodes and historical figures who play a significant role in these stories.

This annotated list contains 174 titles, both novels and short stories, arranged alphabetically by author's name. A full index provides reference to historical persons, places, and events in or essentially connected with New Jersey.

Second edition published 1980: 57 pages, soft-cover. Price $\$ 5.00$.

A Bibliography: The Civil War and New Jersey. By Donald A. Sinclair.

The record of New Jersey's Civil War history is preserved in many written forms, both manuscript and printed. It is with the printed literature that this bibliography deals.

The 1227 entries in this volume, covering 1359 separate items, are arranged by categories: military, political, and religious. While most of the material covers the war, additional sections deal with both the prewar and postwar periods.

Researchers will find this publication a valuable guide to the various books, pamphlets, official publications, magazine articles, and broadsides which pertain to New Jersey and the Civil War.

Published I 968: I 86 pages, hardcover. Price $\$ 9.00$.

A Guide to the Manuscript Collection of the Rutgers University Library. Compiled by Herbert F. Smith.

This guide contains descriptions of nearly 2,000 manuscript groups in the Rutgers Library-papers or records of persons, families, and corporate bodies such as businesses, societies, schools, etc. The description of each group includes an indication of dates, places, size, and subject content.

Published 1964: 179 pages, hardcover. Price $\$ 6.00$. 
A Union List of New Jersey Annual Publications in the Library Collections of the New Jersey Historical Society and Rutgers University. Compiled by Ronald L. Becker and E. Richard McKinstry.

This collaborative effort has produced an indispensable source for students of New Jersey's social, political, and institutional history. The list is divided into sections covering associations, institutions, and government, with convenient subheadings providing access to specific topics.

The 23-page index provides a detailed record of names, places, and subjects categorized in the text.

Published I $977: 75$ pages, soft-cover. Price $\$ 6.00$. 